\title{
Calvin's preaching on the church in the letter to the Ephesians
}

\author{
S J Botha \\ Department of Church History (Sec A) \\ University of Pretoria
}

\begin{abstract}
Dealing with Calvin as preacher inevitably involves attention to his preaching on the church. With this purpose in mind, three sermons from the letter to the Ephesians are analyzed. In this paper the results are discussed under three main headings, namely the origin and the essence of the church, the unity of the church and the offices of the church.
\end{abstract}

\section{INTRODUCTION}

A discussion on Calvin as a preacher inevitably involves particular attention being given to his preaching on the church. This statement may be amplified with reference to the findings of three investigators. W H van der Vegt concludes: 'Thus he [Calvin] is a man of the Church. His title of honour is son of the Church. His God is the God of the Church. To him the children of God are citizens of the Church. The Word of God he calls Word of the Church. Preaching is the preaching of the Church'. (Douma \& Van der Vegt, n d, p 5, own translation).

Benjamin Charles Milner, Jr, who researched Calvin's ecclesiology in most of his writings, is convinced that the total structure of Calvin's theology can be fully comprehended only if his ecclesiology is understood. He puts it in this way: 'In the course of my investigations, however, I became increasingly aware that in working with Calvin's doctrine of the church I was not laboring with an isolated aspect of his theology, but was, in fact, being led straight into the center of his thought' (Milner 1970: preface). Willem van't Spijker, along with Bucer, calls Calvin a theologian of the church and a theologian of the Holy Spirit (Van't Spijker 1994:33).

With these findings in mind and with a view to the theme of this congress, it would seem a logical deduction that the question as to how Calvin's ecclesiology was expressed in his sermons should also be considered.

Because so many of Calvin's sermons, including sermons on the church, are extant and because of the limited scope of a congress paper, a selection had to be made. The theme of the letter to the Ephesians centers on the church and some even characterise 
the theme as 'the Church Glorious' (cf Hendriksen 1972:62; Bruce 1973:13-18), so Calvin's sermons on this letter seemed a good choice. However, as he preached at least forty-eight sermons on this letter, a further narrowing down was necessary (De Greef 1989:103). Accordingly three of these have received attention with a view to this paper, namely the sermons on Ephesians 2:19-22, Ephesians 4:1-5 and Ephesians 4:11-12. These sermons, first published in 1564, appeared in an English translation by Arthur Golding in 1577. Golding's translation provied the basis for the reprint of the sermons published by the Banner of Truth Trust in 1973, of which use is made in this paper.

In analysing Calvin's sermons, one must remember his view that preaching is primarily the exposition of Scripture and, although his sermons were not merely commentary, for him these activities were inextricable. As Dargan puts it: 'In Calvin's preaching the expository method of the Reformation preachers finds emphasis. His commentaries were the fruits of his preaching and lecturing, and his sermons were commentaries extended and applied' (Dargan 1974:449).

Calvin's commentary on the relevant passages from the letter to the Ephesians will therefore be referred to; yet it is interesting to note that at least ten years elapsed between his commentary on Ephesians and his sermons on the letter. His commentary appeared as early as February 1548 along with commentaries on the letters to the Galatians, Philippians and Colossians in a volume dedicated to Prince Christopher of Wirtemberg (Calvin 1948:9). In contrast, according to Denis Raguenier, who from 1549 onwards took down all Calvin's sermons in a primitive form of shorthand, Calvin did not start preaching on Ephesians until 15 May 1558 (De Greef 1989:103). Furthermore, because it is necessary to place Calvin's preaching within the historical context of the Reformation, a few comments must be made about preaching during the Reformation period.

\section{PREACHING AT THE TIME OF THE REFORMATION}

The Reformation marked the beginning of a new era in preaching. The Reformation as such, but also Reformation preaching in particular, could, of course, continue to build on events in the previous century. Yet it is undoubtedly so that the Reformation also brought a total renewal in ecclesiastical life. This also applies to preaching. Indeed, the work of the great preachers and the result of the sermons of this time constitute the great events and successes of the Reformation (Dargan 1974:366).

There was the closest possible connection between preaching and the Reformation. Reformation of doctrine and life profoundly and decisively influenced preaching, and the new preaching, in turn, propagated doctrine and shaped life. The Reformation was 
such a far-reaching and radical event that the determinant impact of its preaching is readily comprehensible. A totally new spirit, power and form now came to the fore in preaching. In the long run, it even had a beneficial effect on preaching in the Roman Catholic Church.

Although the Reformers used other methods as well to disseminate their thoughts, they all recognised the particular value and significance of preaching as a vehicle for reform and they employed it to this effect. For all of them, preaching was a vital element of Christian religious life and therefore an important means of communicating pure Biblical doctrine, as they understood it, to their hearers. Consequently all the Reformers did a very great deal of preaching.

On account of the particular circumstances and problems they had to contend with, the preaching of the Reformers displays polemical and dogmatic features. Yet the most important characteristic of Reformation preaching is the special way of dealing with Holy Scripture. They restored the Bible to its proper place in the pulpit. In matters credenda et agenda they recognised the Bible as their only and absolute norm. Legends about the saints and all manner of extra-biblical stories, which were such an important element in the preaching of the Middle Ages, had no place whatever in the preaching of the Reformers.

Their particular understanding of Scripture was associated with a characteristic way of interpreting Scripture and this obviously influenced their preaching. They abandoned allegorizing and spiritualising exegesis, replacing it with sober, clearly grammatical and instructive exposition. Strong emphasis was placed on the interpretation, explanation and application of Scripture and subservience to the rules of rhetoric was thrown overboard. The analytical method was preferred, with a text-by-text interpretation, resulting in what was called lecto continua. Although the homiletic method varied from person to person, this particular method of Scriptural interpretation led the Reformers quite naturally to the homilia of the early church as the most suitable and desirable method. The Reformation age produced many great preachers and among them John Calvin, of whom it has been said that his genius outstripped them all (Dargan 1974:440).

\section{THE THREE SERMONS BASED ON THE LETTER TO THE EPHESIANS}

For the sake of a systematic approach, three main themes are distinguished - the origin and essence of the church, the unity of the church and the offices of the church - each of which falls into further sub-sections. Although each of these main themes occurs in all three of the sermons, it may be said that in this sequence the main themes 
provide the focal points of the three sermons being considered. This does not detract from the fact that other elements may also be identified in these sermons (cf Parker 1975:94).

On the formal side, some comments are necessary. The three sermons differ from each other in respect of length, structure and style, but they are in conformity with other researchers' findings on the sermons of Calvin (Dargan 1974:449; Parker 1975: 91). Although the unity of Scripture is constantly presupposed, Calvin allows the particular message of the passage under consideration to be heard with as much clarity as possible. It is a characteristic encountered in his commentaries also that he confined himself with remarkable strictness to the text of a document in his concern to do justice to the author's intention (Parker 1975:94). In respect of these three sermons too he clearly expounded and applied only the passages before him.

\subsection{Origin and essence of the church}

Under the sub-heading The church is God's creation the origin and essence of the church will be dealt with. From his discussion of the various metaphors for the church used in the texts, Calvin's understanding of the essence of the church emerges. Therefore these images are briefly referred to.

\subsubsection{The church is God's creation}

In the introductory sentence of the first sermon Calvin speaks very clearly of God '... pulling us back from the dungeon of death to make us his children and heirs of the heavenly life' (Calvin 1973:213). In this pronouncement Calvin links directly with the pericope, indicating the result of the Ephesians being 'no longer strangers and foreigners'. However, this result is only possible because God has acted. God is therefore the active subject, and in any discussion on the church this must be taken into account. For Calvin it was a firm point of departure that the church exists, that the church continues to exist, that the church has a future towards which it is en route, exclusively owing to the fact that God has acted, is acting and will act. In all three sermons this is clearly presupposed. Whatever may be said about the church, whatever metaphor may be used, it must al-ways be remembered that the church is God's creation and therefore his property, with which he is involved. Whether the church is compared to a city or a state of believers or to the family of God or to the Temple of God, as happens in these particular verses, for Calvin the church was a living organism because of God's continuing active presence. 
Becoming citizens of God's kingdom or, more intimately, members of his household, living closely and confidently with him, is possible only because God in Christ has made sinners his children by adoption (Calvin 1973:214). The foundation of the temple is given by God and the building up of the temple is accomplished by him. In the second sermon too, where the unity of the church is the focal point, it becomes evident that Calvin regards the unity of the church also as the creation and gift of God. Therefore he says that in the first few verses of Ephesians Paul presupposes that the faithful have their unity in God. It is only because God himself creates unity through his one gospel with only one hope that there can be any question of unity (Calvin 1973:324). In the third sermon it is even clearer how Calvin sees God's active presence in the church, which is his creation. He says that although Jesus Christ is exalted high above the heavens, 'we always find him present by the power of his Holy Spirit, and by that means he fills all things' (Calvin 1973:361).

Furthermore, the church is not a creation of God dating only from the advent of Jesus Christ. Therefore Calvin understands the toon hagioon of Ephesians 2:19 as referring not only to all the believers now alive, but, as he puts it, 'all the patriarchs and faithful servants of God, even ... all the angels of paradise' (Calvin 1973:213) belong to the church. For Calvin, the beginning of the church lies much further back in the past than Pentecost, for instance. He even refers to Adam and Eve as members of the church. An example of this is his commentary on Genesis 4:25:

\begin{abstract}
Adam and Eve, with a few other of their children, were themselves true worshippers of God .... We might rightly conclude that Seth was an upright and faithful servant of God. And after he begat a son, like himself, and had a rightly constituted family, the face of the church began distinctly to appear (exstare coepit distincta ecclesiae facies), and that worship of God was set up which might continue to posterity.
\end{abstract}

(Calvin 1949:222)

Milner explains this view of Calvin's as follows: 'Taken together, then, the metaphors suggest that the church is conceived with Adam and Eve, foetally develops under the patriarchs, is born at the Exodus, and - together with these - has Abraham for its father' (Milner 1974:9).

The moment Calvin begins to speak about the fall, therefore, he begins to speak about the church as God's creation. From his commentary on Genesis 15:10 it is clear that he represents the creation of the church, which is also a creatio ex nihilo, as a rais- 
ing from death and the grave (Milner 1974:47). From the distorted post-lapsarian creation, which means nothing but death, God is at work, constantly gathering together those who belong to his church. With this in mind, Milner concludes with reference to Calvin's understanding of the church: 'The church is not so much an institution in history in which the restoration of order has been accomplished, as it is itself the history of that restoration' (Milner 1974:47). Milner demonstrates that for Calvin the church is intimately linked with the restoration of order in a fallen world. For this reason, Calvin sees the church as a living, dynamic organism, created by God to restore order in creation and to live to the glory of God (Milner 1974:47). No wonder it is confessed among the followers of Calvin, in the words of the Belgic Confession: 'This Church has been from the beginning of the world and will be to its end ...' (Belgic Confession, Article 27).

\subsubsection{The church as God's temple, with Jesus Christ as foundation and corner stone}

Both in the first sermon and in his commentary on Ephesians 2:19-22, Calvin draws attention to the different metaphors that are used for the church and to their particular significance. In the introductory sentence of the sermon he suggests that in these images Paul provides us with a mirror, as it were, in which the infinite goodness of God is clearly to be seen. For it is precisely these images that express how tremendous the issue is that is at stake here (Calvin 1973:213). In his commentary too, Calvin says the variety of images brings home the vast significance of the honour and favour God has shown the Ephesians (Calvin 1948:241-242).

In line with the verses dealt with in the sermon, he gave most attention to the third image, namely that of the church as a building and, more specifically, a temple built for the Lord. In his first sermon, Calvin first examines the image of the church as the temple of the Lord, before looking at the supporting images of the foundation and the corner stone.

Calvin is emphatic that it is not contradictory to describe both the church as a whole and the individual believer as God's temple. Because the Holy Spirit lives in individual believers, each can be a sanctified temple of God. Then, in relation to the greater whole, the image changes and each believer is seen as a living stone built into the greater whole, which can also be seen as the temple in which God himself has his dwelling (Calvin 1973:214). Apart from the fact that the image of the temple refers to the unity of the church, a matter to which Calvin later reverts more fully, it also fully assures believers that if they are built together into God's temple, they will always have him in their midst and that, when they call on him, they will always find him near at hand (Calvin 1973:214). 
Calvin then goes on to discuss how God does this building work. He says that the Ephesians who were previously heathen were built up by the gospel to be made temples for God. It is precisely by knowing the doctrine of the gospel that people are enabled to understand the other images, namely being citizens of his state or, more intimately, members of his household. Obedience to the gospel, acceptance of the promises God makes there, means being built into this temple and being built up into the spiritual building in which God wishes to make his abode. This, Calvin says, needs no lengthy discourse; one need not travel all over the heavens and the earth in search of the doctrine of the gospel. On the basis of Paul's reference to the foundation of the apostles and prophets, Calvin contends that: '... since God has spoken by Moses and his prophets, and finally by his apostles, we ought to assure ourselves that all that is contained in the law and in the gospel is the truth in itself, and that we ought not to be afraid to be imposed upon or deceived (Calvin 1973:215).

It is important to note that Calvin here reverses the words apostles and prophets because he here understands prophets as the prophets of the Old Testament and not as the New Testament prophets, which is the way he interprets it in Ephesians 4:11 (Calvin 1948:278-279). He reverses the order in his commentary on Ephesians 2:20 as well (Calvin 1948:242). In addition, he uses the name of Moses as an indication that he here understands prophets to refer to the entire Old Testament. As a synonym he also uses the expression the Law, the prophets and the gospel. In this way he wishes to signify that one does not have to search afar for the gospel, the Word of God, for that Word is contained in the Bible, Holy Scripture, the Old and New Testaments. Therefore, he emphasises, we do not need to become flustered when the receiving of God's Word is questioned, for it has pleased God to make it known through the prophets and apostles as instruments of his Holy Spirit. All that is required of us is the humility to receive it (Calvin 1973:215).

Calvin is convinced that the law, prophets and gospel definitely concur. It is true that the ceremonial aspect of the law no longer applies, but the substance retains its force. He goes on to say that it is not the case that when the gospel was preached to the world, God changed or began to teach in a strange way that had nothing to do with the law (Calvin 1973:216). Calvin explicitly declares that 'the law and the prophets all bore witness to our Lord Jesus Christ' (Calvin 1973:216). Although it is indeed true that 'all perfection of wisdom is thoroughly contained in the gospel' (Calvin 1973:216), the faithful are edified by the whole Bible: they are built up into God's temple by the law and the prophets and the apostles.

Calvin does not doubt that the whole Bible communicates a single message and this message is Jesus Christ. Therefore he says: 'We see then that all that is ever dealt with in the holy Scriptures is now verified in our Lord Jesus Christ, to show us how 
that he is the whole of that which we have to take hold of' (Calvin 1973:217). From this it follows that the foundation of the apostles and prophets refers to Jesus Christ himself. For this reason, nothing may be taken away from the Scriptures, as Marcion did, and nothing may be added to them, as Rome has done in elevating tradition to the same level of authority as the Bible (Calvin 1973:219).

Clearly the building up of God's temple is not a matter quickly disposed of. It is a lifelong task. The proclamation of the doctrine of the prophets and apostles is vital for the existence and survival of the church (Calvin 1973:219). Here Calvin is obliged to refer in passing to the offices of the church, when he says that those who are ordained to preach may be called masons and carpenters (Calvin 1973:219), fellow-builders of God's temple along with the prophets and apostles, provided they continue to draw from the pure fountain of Holy Scripture alone (Calvin 1973:220).

The image of the church as the holy temple of God, the handiwork of God, the competent master-builder, is elaborated by means of the supporting images of the foundation and the corner stone. Calvin develops these images, beginning with a warning: 'Again, when St Paul says that Jesus Christ is the foundation and the chief corner stone, it is not meant that it is lawful to mix anything with Jesus Christ, as though he should be only one piece of the building, and the rest be supplied by others' (Calvin 1973:220).

What Calvin is warning against here is the Roman Catholic practice of honouring patron saints and other advocates as well as the idea of obtaining merit through our own good works (Calvin 1973:221). He goes on to say: 'This wrong and outrage that they commit against our Lord Jesus Christ well deserves that he should dismiss them and that by this means they should be cut off from God's church' (Calvin 1973:221).

Positively, Calvin asserts that Jesus Christ is the only foundation on which the church can and may be built because God revealed himself fully through Jesus Christ and entrusted to him everything required for our salvation or worthy to be desired (Calvin 1973:220-221). Here Calvin's preaching is in full accord with his commentary. Yet it is important at this point to quote a passage from his commentary:

'... Christ is the only foundation. He alone supports the whole church. He alone is the rule and standard of faith. But Christ is actually the foundation on which the church is built by the preaching of doctrine; and, on this account, the prophets and apostles are called builders (1 Cor, 3:10). Nothing else, Paul tells us, was ever intended by the prophets and apostles, than to found a church on Christ.

(Calvin 1948:242-243) 
The same understanding must inform our interpretation of the image of Jesus Christ as the corner stone. Thus Calvin declares: 'And this in effect is the way in which we ought to apply this text, where it is said that our Lord Jesus Christ is the chief corner stone in such a way that he bears up the whole building in the corner, and we know that the greatest weight of a building lies upon the corner' (Calvin 1973:221).

Calvin hastens to add that this does not mean that the image of the corner stone merely implies that Jesus Christ is first in rank and that there are other stones with mastery and authority alongside him. Just as Jesus Christ is the only foundation on which to build, so too he is the only corner stone, the keystone that binds the spiritual building into a unity in which God intends to dwell. If our faith does not rest on the Lord Jesus Christ alone, there can be no question of building. The slightest deviation from the foundation of Jesus Christ or failure to build on him as corner stone will cause the whole structure to collapse.

Here Calvin has to contend against the Roman Catholic claim that the See of Rome is the foundation of the church. He rejects this claim as an abuse of the Lord Jesus Christ's words to Peter in Matthew 16. In strong language he rejects the Roman Catholic view, labelling it cursed presumption, a lack of reverence for Scripture, intended to set up a tyranny and a manifest blasphemy. Instead of offering God's Word as food for the world, the Roman Catholic Church has buried it (Calvin 1973: 224). It is hardly surprising that he refers to the hellish assemblies that are in popedom' from which the faithful must get away and stay away, for there the Antichrist reigns and Jesus Christ is dispossessed of his right and sovereignty (Calvin 1973: 224). Calvin cautions: ' $\ldots$ we do not belong to our Lord Jesus Christ, nor can we be of God's church, except it be by following the pure doctrine of the law and the gospel, and by forsaking (as one might say) all the filth and abomination that men have devised by their own dreams and fond ideas, no matter how fair a semblance of wisdom they bear' (Calvin 1973:222).

\subsubsection{The church as the body of the Lord Jesus Christ}

In Ephesians 4:12 the church is called the body of Jesus Christ. Although Calvin touches on it, he does not provide a detailed exposition of the image. This may be attributed to the fact that the expression is used in a passage where Paul is dealing with the offices in the church and their function. Yet Calvin subsequently refers to this image, describing it as an 'honourable title', which shows how precious the church is and how precious its unity is (Calvin 1973:374). 


\subsubsection{Unity of the church}

In the sermon on Ephesians 4:1-5 the unity of the church is the focal point. In the very first sentence Calvin announces this theme, namely '... how God's children ought to be joined together, so that every man may help his fellow and encourage and strengthen him, and all of us endeavour with one accord to serve God' (Calvin 1973:317).

The matter of the unity of the church had already been raised in the sermons on Ephesians 2:19-22 and Ephesians 1:11-12. In the first sermon the metaphors of city and state, household, spiritual dwelling and temple, with the associated supporting images of foundation and corner stone, inevitably suggest the idea of unity. Therefore Calvin says: 'We see also that to be accounted God's children we must give our minds to true concord' (Calvin 1973:222). In the third sermon too, where the focus is on the offices, the unity of the church is raised: 'When we are so joined into the one body of the church, we have a form of government which it is impossible for us to set aside by reason of our ignorance and the weakness of our faith' (Calvin 1973:372). In his commentary Calvin states specifically that church government purposes the maintenance of unity. In the introductory paragraph of the commentary on Ephesians 4 he says: "The three remaining chapters consist entirely of practical exhortations. Mutual agreement is the first subject, in the course of which a discussion is introduced respecting the government of the church, as having been framed by the Lord for the purpose of maintaining unity among Christians' (Calvin 1948:266).

Calvin certainly took to heart the Scriptural call to unity. Therefore it may rightly be said with Balke: 'The unity of the church has the heart of Calvin' (Balke 1992: 131).

\subsubsection{The unity of the church demands self-denial from the member}

As early as the second sentence of the second sermon Calvin makes it plain that to have unity and to serve God with one accord necessitates self-examination on the part of each member, the acknowledgement of faults that will have to be abated, struggled against, put away. Self-exaltation, presumption, pride, severity and rigour are the ills specified by Calvin which, we know from experience, beset all of us (Calvin 1973: 317). These faults are rooted in human nature and from them flow further evils such as contempt for others, ambition, spitefulness and ultimately party strife in the church (Calvin 1973:318). This is the exact opposite of that to which the faithful are called in order to maintain unity, that is modesty, friendliness, patience and forbearance. For this reason, Calvin does not see Ephesians 4:2 in the first place as an exhortation and instruction, but rather as a warning: 'And here we have to note first of all how St. 
Paul in speaking of lowliness, meekness, and patience, warns us that if we are not wary, and every man check himself, the devil will always gain easy access and entrance to us to trouble us' (Calvin 1973:318).

To carry out our calling to maintain unity in the light of this warning demands of us as believers that we acknowledge our weaknesses, our pride and self-exaltation, that we turn from them and live with our fellow-believers in humility of spirit. We must be willing to embrace, forgiving their weaknesses and shortcomings, however difficult this may be, in the knowledge that they too show forbearance towards us (Calvin 1973: 320).

This requires nothing short of self-denial. Therefore Calvin contends 'that we shall never be meek, never have any gentleness and mildness in us, until we are brought low' (Calvin 1973:320). The believer will humble himself only in resorting to Jesus Christ, who freely lets us come to him. And we, for our part, may freely turn to him since Jesus Christ himself knows the meaning of temptation: 'In order that we for our part should not hesitate to resort to him freely, and in order that we should be heard by God the Father for his name's sake, it is said that he had compassion on us, because he had felt what man and man's infirmities are, without any taint of $\sin$ however ...' (Calvin 1973:320).

However, an attitude of humility and self-denial does not make everything acceptable and permissible for the church. There must be a proper balance in respect of weaknesses. Calvin says there are two extremes, both of which are wrong. The first is to turn a blind eye to what is sinful and wrong and, instead of opposing it and disapproving of it, to make use of flattery. In this regard Calvin Says: '.. those flatteries are no better than plasters to ease the sore, and in the meanwhile to feed the rottenness within' (Calvin 1973:321).

The other extreme, which Calvin also rejects, is excessive rigour in respect of even the most trivial offence: ' $\cdots$ he that can overlook nothing, but is so terribly stern that all sins are in his opinion unpardonable, shows that there is no humanity in him (Calvin 1973:322). Only those who in all meekness hold on to Jesus Christ and are led and governed by God's Spirit will be willing to forgive and to bear with one another in the kind of love of which 1 Corinth 13 speaks (Calvin 1973:322). Something that emerges from these thoughts of Calvin is that he was not the rigid, implacable, intolerant figure he has been made out to be. While he was not a theolo-gian who was inclined to all kinds of compromises, he showed great suppleness, as is clearly evident here in his attitude towards unity (Balke 1992:131, own translation). 


\subsubsection{The unity of the church as a gift and a task}

In speaking about the unity of the Spirit or the unity achieved by the Spirit, Calvin says: 'However, it presupposes here that the faithful are at one in God ...' (Calvin 1973:324). He even calls the unity forged by the Spirit an essential mark of the church and flock of God (Calvin 1973:323). From this it is clear that for Calvin the unity of the church is not something that is still to be achieved by the faithful. It is something that is given by God, that is achieved by his Spirit. Being united to God means being united to our fellow-believers. And if we deny or denigrate unity with our fellowbelievers, our union with God is in question.

For Calvin, expressions like one faith, one baptism, one God and Father of us all in the text link the unity of the church inextricably to the Triune God, to who he is and what he does. There is but one God, the God of peace, who accomplishes the one faith and commands the one baptism. Therefore those who are united to him are also united to one another and are therefore one.

Dealing with the expression 'one Lord', Calvin says: 'It is certain that by this he [Calvin] means one God, who has sovereign dominion over us, and is our master to keep us in unity, because he cannot suffer us to be divided' (Calvin 1973:328).

Believers bound to the God of peace, who are united by one faith and one baptism, are commanded to live together in peace. God would not be able to endure contention and would not be able to make his dwelling among men who are at strife. This thought makes Calvin ask: 'Do we think we can involve him in our troubles and contentions, our quarrels, violence and outbursts'? (Calvin 1973:328).

Just as there is one gospel, so there can be only one true faith, by which believers are bound together already in this world, for they have only one common heritage (Calvin 1973:329). Calvin emphasises that the one faith does not represent an accord to which human beings have of themselves come. The one faith is possible only because God has brought them to it. Neither would they be able to persevere in the one faith unless God empowered them to do so (Calvin 1973:330). Calvin says: 'There has to be then a reciprocal bond between faith and the gospel. Just as the gospel of which God is the author is one, so also our faith must be but one' (Calvin 1973:330).

There is only one baptism ordained by God, by which visible sign God calls the elect to himself to put on Christ and to be joined to him and thus to be partakers of his life and of all his benefits. There is only one God, Father, Son and Holy Spirit, who instituted one baptism, making it a powerful sign of his will to save us in and by Jesus Christ. Therefore all who are baptised are bound together into one body and receive from the same God the command to serve him with one accord. So too, the expressions one Spirit and one hope point to the unity given to the church. Jesus Christ is one and as his body, the church, consisting of all the believers, is one. Thus Calvin says that 'we are made, as it were, all one man in Jesus Christ' (Calvin 1973:326). He 
also uses marriage as an image for the unity that is given to the church, saying that 'the church is bone of our Lord Jesus Christ's bone and flesh of his flesh' (Calvin 1973: 326-327).

When the one Spirit leads and governs believers, he binds them to a unity, so that the whole body of the faithful 'is but as one man' (Calvin 1973:326). The unity given the church also consists in the fact that 'we are all called to one inheritance' (Calvin 1973:327). This means, Calvin says, that 'there is a much holier union between us than there is between the natural brothers of this world' (Calvin 1973:327). With regard to the inheritance he declares: 'We have an inheritance that cannot be divided up. It is not a question of saying, I have that which belongs to me, I will get me away, and I will stand aloof' (Calvin 1973:327).

However, the gift of unity brings with it a task, a calling and a responsibility with regard to the gift. As Calvin puts it: 'Now if we are all so joined together to the Son of God, it is reasonable also that we should agree among ourselves, and that the union should extend throughout all the body, for the two things are incompatible, that our Lord Jesus Christ should reign over us, and yet nevertheless that we should be divided among ourselves, seeing that he is but one' (Calvin 1973:327). Calvin is not explicit on the point of how the one must accord with the other. What he does say, however, is that mutual division cannot be a revelation of the gift of unity, neither can intolerance or forsaking of one another. His warning is clear and sharp: '... If any of us withdraw from his brethren, it is just as if he gave up his part in the kingdom of heaven' (Calvin 1973:327).

Positively expressed, our unity emerges in, and is promoted by, unanimity in our confession of faith, our joining together in serving him, but also mutual serving of one another. Therefore Calvin says:

As touching the doctrine, it is not enough for us to confess God altogether with one mouth, but it must also teach us to keep ourselves so linked together in one unity that each of us applies himself to his neighbour's benefit. We have to consider how we may serve ... bearing with them that are weak, honouring them that have received more largely of God's gifts ...'

(Calvin: 1973:330)

It is not up to believers to accomplish unity with God or one another. It is something that is given because God has already accomplished it. What is required of the believer is, on the one hand, to be conscious of the danger of damaging unity by the weaknesses and sin that can be caused by discord and strife. On the other hand, the believer is 
called to perseverance in the common faith; unity and obedience in serving God and self-denying service of one another.

In his third sermon too, in which Calvin focuses on the offices of the church, he returns to the unity of the church and the maintenance of unity. He insists that Jesus Christ instituted the offices precisely in order to bind his faithful people together in unity. Therefore all believers must accept the government of the church by pastors, as ordained by God, because they stand in need of it. He calls it a remedy given by the Lord Jesus because he knows our human weakness and unwillingness (Calvin 1973: 372-373). Government by pastors and teachers was given for the edification of the body of Christ. Then he warns those who will not accept Christ's government through the offices by pointing out that Paul uses the honourable title of body of Christ with reference to the church specifically in order to emphasis what a heinous sacrilege it would be to seek to rend in pieces the body of Christ (Calvin 1973:374).

In the words of Calvin the church's task in respect of unity consists in this:

If we earnestly desire that God should be honored and served ... if we are his people and are under his protection, if we covet to be built up in him and to be joined to him, and to be steadfast in him to the end; to be short, if we desire our salvation, we must learn to be humble learners in receiving the doctrine of the gospel and in harkening to the pastors that are sent to us.

(Calvin 1973:374)

The pastors, for their part, must proclaim only the Word of God, for there is no way in which the church can be built up and inviolably preserved other than by means of the proclamation of the Word.

\subsubsection{The unity of the church and the truth}

Calvin's fiery pleas in the second sermon for the preservation of the unity of the church and his use of statements such as 'the church shall perish ... if we do not continue in quietness and shun all strife and debate' (Calvin 1973:324), and that for believers, unity is 'the way in respect of which we are acknowledged as God's children' (Calvin 1973:323) almost create the impression that he is thinking of an unconditional unity to be maintained at all costs. However, this is by no means the case. As has been indicated, he was not a theologian of compromises and he saw no solution whatever in relativism. For this reason Calvin was not a proponent of a unity that overrides credal 
divisions (Balke 1992:131). In his first sermon already, where unity is briefly touched upon, Calvin does not neglect to formulate specific conditions for unity. Thus he says that the true point of departure must be the pure doctrine handed down from the prophets and apostles (Calvin 1973:219). For this reason he rejects the unity of which the Roman Catholic Church boasts as false and he rejects union with that church as impossible. Despite Rome's boasts of being the church of God, it does not manifest an essential mark of the church, since the doctrine of the prophets and apostles is not honored and maintained. He sharply contends that the papists obscure, falsify, corrupt and banish the holy Scriptures by their own inventions, even while they profess to accept them. His conclusion is that the Lord disowns them and even abhors them. He calls the Roman Catholic Church a hunchback, a misshapen body and a monster and warns that it is impossible for one who 'does not get himself out of the den of thieves' to be joined to Jesus Christ (Calvin 1973:223).

For Calvin, clearly, union with Rome was totally excluded. Consequently he held it against those who claimed to acknowledge the truth of the gospel but chose to stay in the Roman Catholic Church for particular reasons. In 1552 he dealt with this in a sermon on Psalm 16:4. This, he said, was nothing but cowardice, for thereby they were defiled by the abominations of Rome and indeed denied the Son of God (Milner: 1970:147). Only within the true church, where the pure doctrine is proclaimed, can the faithful be built into a temple in which God dwells. Only then can there be any question of true unity. In the second sermon Calvin maintains this position unalloyed. He insists that mutual peace which should be an expression of unity, but which lacks a good foundation, cannot be pleasing to God, but will rather be accursed. There can only be unity and peace if the believer is directed to God alone (Calvin 1973:324). He is blunt in stating his view of what union with papists would entail: 'We should have to forsake the pure doctrine of the gospel and to set up ourselves against God and defile ourselves with all kinds of filthiness and abominations. But it would be better if the whole world were sunk, and we with it, than to seek such a peace (Calvin 1973:324).

There can only be unity between people, including believers, if it is grounded in attachment to God and the Lord Jesus Christ. Calvin does not comment in the sermon on the relationship with the Lutheran churches or even the organisational link with Reformed churches elsewhere. What must be borne in mind is that for Calvin the primary issue was the church of Geneva and its unity and accord. Bouwsma concludes that for Calvin the thought of institutional unity was futile for two reasons. First, it was not attainable in the context of the prevailing political realities and furthermore, it was not necessarily desirable in the light of the consequences of papal tyranny (Bouwsma 1988:215). Calvin was indeed very active in the ecumenical field. In fact, he has been called the first ecumenist in church history (Balke 1992:130). 


\subsection{The offices in the church}

The offices in the church provide the focal point of the third sermon on Ephesians 4:11-12. This is not surprising as these two verses have been described as the foundation texts in dealing with the concept of ministry or order in the church (Pont 1979:11).

\subsubsection{Jesus Christ and the offices}

Calvin firmly holds that where the offices function, God himself is present in the person of his only Son (Calvin 1973:368) and that the offices are nothing other than instruments and channels of the Holy Spirit (Calvin 1973:369). That this was Calvin's conviction is already evident from the opening sentences of the sermon, to the effect that although bodily Jesus Christ is exalted to heaven, yet he is present to the church by the power of the Holy Spirit to perform and fulfill all his promises. In the third sentence he says that the manner of Christ's filling all things is 'in order that every faithful man should with all lowliness avail himself of the gifts and grace which it has pleased our Lord to bestow upon those whom he has set in the church to govern it' (Calvin 1973:361).

How Calvin understood the matter becomes very clear when he subsequently returns to this theme and says that it might be thought strange that Paul, instead of speaking about the gifts of the Holy Spirit, brings us to the offices. He ties this in with verse 7 where Paul says that 'grace is given to every one of us according to the measure of Christ's gift'. Then in verse 11 Paul tells us that the diversity of gifts is dispensed in the five offices, although Calvin comments here that Paul does not really seem to pursue his original point (Calvin 1973:370).

But, Calvin points out further on, what must be noted is that Jesus Christ does not merely institute offices, but 'equips them there and then with what is necessary for the execution of their office' (Calvin 1973:370). Jesus Christ indeed called the apostles and equipped them for their task of heralds of the gospel. In calling men, he joins his gifts for the good of the church inseparably to his charge. In his commentary Calvin says: 'He whom God has appointed to be an apostle does not bear an empty and useless title; for the divine command, and the ability to perform it, go together' (Calvin 1948:277).

Calvin repeatedly emphasises that this is the order instituted by Jesus Christ and that it must be accepted and obeyed by ministers and members. To the members he says that although it goes against the grain for natural man to accept anyone set over him, this is nevertheless how the Son of God determined to deal with the faithful. Therefore Calvin says: '.. that when we have good and faithful teachers and others 
that labour to show us the way of salvation, it is a sign that our Lord Jesus Christ has not left us, nor forgotten us, but that he is present with us, and watches for our salvation' (Calvin 1973:363).

To the ministers Calvin says that there cannot be good and faithful teachers unless Jesus Christ himself accomplishes it. He adds the caution that anyone who opposes this order, in which Jesus Christ governs through those called and endowed by him, must bear in mind that he is resisting God himself (Calvin 1973:364). The fact that there is a diversity of gifts is part of the order instituted by Jesus Christ with a view to the welfare of his church. Thus he provides fully for those who belong to him. All have not received the same gifts, precisely because Jesus Christ is so fully concerned to bring all the faithful to the heritage of salvation.

The five offices have one thing in common and that is that their primary task is to preach the gospel and expound the holy Scriptures (Calvin 1973:362). Furthermore, the church is not built up in any other way than through the preaching of the Word (Calvin 1973:374). In principle there is therefore no difference with regard to the task assigned. The great difference consists in the fact that some of these offices were temporary and not bound to a single congregation, while others are permanent and tied to a particular place.

\subsubsection{The temporary offices}

\subsubsection{The apostles}

Calvin says that the office of apostleship was ordained for the proclamation of the doctrine of the gospel 'in all regions and countries' (Calvin 1973:364). Because their commission was to preach the gospel to all nations, the apostles could not be bound to a particular place but had to avail themselves of every opportunity they were presented with and make use of every door that opened to them in order to fulfill this mandate, although not everyone who heard them came to faith. 'But', Calvin adds, 'after the gospel was thus authorised the office of apostleship ceased' (Calvin 1973:364).

\subsubsection{The evangelists}

Of the evangelists Calvin says that they were companions and helpers of the apostles who 'were not of equal status, but yet in commission with them, to sow the seed of salvation here and there' (Calvin 1973:364). They too were not limited to one congregation. Summarising these two offices Calvin says: '... that the apostles were like trumpets to proclaim the gospel everywhere, and that they had with them evangelists in a similar charge to bear them company' (Calvin 1973:366). 


\subsubsection{The prophets}

Here, in contrast to Chapter 2:20, Calvin thinks in terms of New Testament prophets. They were called to be expounders of God's will. They were tied to a particular place, but in some congregations there were more than in others, although every congregation in the early church had a prophet. Calvin then refers to what Paul wrote to the Corinthians about the gift of prophecy, from which it appears that this gift enjoys precedence over other gifts because it is most conducive to the edification of the church.

From the sermon it emerges that Calvin's view was that the prophetic office was not originally intended to be a temporary office, but that in practice God caused this office to cease functioning, diminishing his gifts because of the world's ingratitude. This does not mean that God does not still ensure that all that is necessary for salvation is available to all the elect. As Calvin puts it, 'We are unworthy to have his treasures so greatly poured out as was the case at the beginning of the gospel' (Calvin 1973: $364)$.

Without elaborating on it, Calvin avers that the prophets had far more knowledge of the Scriptures than those in the office of teachers. If one consults Calvin's commentary, there are slight differences from his sermon. In respect of the apostles, he accords them two further tasks besides preaching the gospel throughout the world, namely to found churches and to establish the kingdom of Christ. In his sermon he does not give specific attention to these points (Calvin 1948:279).

In his commentary he makes it very clear that the prophetic office was purely temporary. From the sermon, however, a less rigid interpretation is evident. With regard to the evangelist, he says in his commentary that it was a temporary office: '... except in those cases where religion has fallen into decay, and evangelists are raised up in an extraordinary manner, to restore the pure doctrine which has been lost' (Calvin 1948: 280).

In the sermon he does not depart from this view, and it is evident that he obviously regarded the Reformers as such extraordinary evangelists from his statement that 'It was absolutely necessary, considering the confusion and disorder of the popedom, that God should stir up men who were not always chosen according to the order of the church; but he gave them grace and he used them' (Calvin 1973:366-7).

\subsubsection{The permanent offices: pastors and teachers}

Calvin regards the pastors and teachers as the permanent offices through which Jesus Christ always cares for his church. He explicitly states: 'Let us assure ourselves that God offers himself to us in the person of his only Son, when he sends us pastors and 
teachers' (Calvin 1973:368). Through these two offices Jesus Christ governs his church, with the result that his Word is always near at hand. Through them the faithful learn to know the will of God, for they are proclaimers of his will.

Calvin is emphatic that these are two separate offices, although he does concede in his commentary that the among the Fathers, John Chrysostom and. Augustine saw them as a single office (Calvin:1948:279). He agrees with them that Paul does not always make a clear distinction, but he says that he does not regard this as a sufficient reason not to distinguish between the offices. Thus he says in his commentary: 'Teaching is, no doubt, the duty of all pastors; but to maintain sound doctrine requires a talent for interpreting Scripture, and a man may be a teacher who is not qualified to preach' (Calvin 1948:280).

Yet Calvin links the two so closely that they almost appear to be one office. Thus he says that the pastors are ministers of the Word with the ordinary charge of teaching in a particular place. Then in the next sentence he says: 'As much is to be said of the teachers'. Yet in the following sentence he distinguishes the offices, as he does in his commentary:

It is true that no-one can be a pastor unless he teaches, but yet for all that, the teachers have a separate responsibility of their own, which is to expound the Scripture that there may always be a good and sound understanding of it ... so that heresies and false opinions may not spread, but that the faith may abide firm and sure above all things. To that end served the teachers.

(Calvin 1973:365)

It is evident that Calvin understood pastors to refer to ministers of the church and teachers to lecturers in theology. From both his sermon and his commentary it is clear how important for the existence and survival of the church the two permanent offices were in his view. Thus he says that without pastors all would end in confusion and chaos in the church and that without pastors and teachers there can be no order whatever in the church. They are the instruments by which Jesus Christ speaks and draws us to himself (Calvin 1973: 375). Therefore obedience to the offices is obedience to the Lord himself.

This does not mean that Calvin thinks in terms of a single ruler like the Pope. He utterly rejects the Pope's claim to be Vicar of Jesus Christ in the world (Calvin 1973: 372). In his commentary he goes so far as to say that Paul's teaching here is insulting to papal claims (Calvin 1948:280). What Calvin has in mind is rather a meeting of the 
office bearers in each congregation. In his sermon he says: "And that is not to have a Pope, but every church has pastors and teachers according to its need, according to the number of people, and according as the place requires' (Calvin 1973:372).

\section{CONCLUSION}

* None of Calvin's three sermons provides a logical discourse on the doctrine of the church. Yet it is possible to form a reasonable - even clear - image of how Calvin thought of the church in general and of particular aspects of the church.

* All three of the sermons testify to how seriously Calvin took the primary task assigned to the pastors in the Ordonnances Ecclesiastiques, namely '... to proclaim the Word of God, to instruct, admonish, exhort and censure, both in public and private' (Calvin 1954:58).

* From all three sermons it emerges that the offices of pastor and teacher fall together. In accordance with the Ordanances that the minister's task was 'instruction of the faithful in true doctrine, in order that the purity of the Gospel be not corrupted either by ignorance or by evil opinions' (Calvin 1954:62), there is in all the sermons a strong element of teaching of true doctrine and rejection of false doctrine.

* The particular aspects of Calvin's thinking on the church that emerge from his three sermons do not differ significantly from his ecclesiology as contained in his Institutes and other works. Indeed, this is already evident from the very first paragraph of Book IV of the Institutes.

* The findings of other researchers support this conclusion. Examples are, inter alia, Benjamin C Milner's work Calvin's Doctrine of the Church; Calvinus Oecumenicus; Calvijn en de eenheid der kerk in het licht van zijn briefwisseling of W. Nijenhuis; and, finally, Louis Gaumaz' Het ambt by Calvijn.

\section{Works Consulted}

Balke, W 1992. Omgang met de Reformatoren. Kampen: Uitgeverij De Groot Gaudrian.

Battles, F L 1980. Analysis of the Institutes of Christian Religion of John Calvin. Grand Rapids, MI: Baker Book House.

Bauwsma, W J 1988. John Calvin: A sixteenth-century portrait. New York, Oxford: Oxford University Press. 
Botha, S J 1995. Kerkbegrip en Kerkorde. HTS 51/3, 753-770.

Bruce, F F 1961. The Epistle to the Ephesians. London: Pickering \& Inglis.

Calvin, J 1948. Galatians-Ephesians, tr by W Pringle. Grand Rapids, MI: Eerdmans. 1949. Commentaries on the firts book of Moses called Genesis, tr by J King. Grand Rapids, MI: Eerdmans.

1954. Calvin: Theological Treatises, ed by J K S Reid. Library of Christian Classics, Ichthus edition. Philadelphia: Westminster Press.

Calvin, J 1962. Institutes of the Christian Religion, tr by H Beveridge, two vol. London: James Clarke

1973. Sermons on the Epistle to the Ephesians. Revised version of Arthur Golding's translation. Edinburgh: Banner of Truth Trust.

Dankbaar, W F 1957. Calvijn: Zijn weg en werk. Nijkerk: S F Callenbach.

Dargan, E C. A history of preaching. Michigan.

Dauma, J \& Van der Vegt, W H n.d. Het gepredikte Woord: Preken van JohannesCalvijn over de Kerk. Faneker: T Wever.

De Greef, W 1988. Johannes Calvijn: Zijn werk en geschriften. Kampen: Uitgeverij De Groot Gaudriaan.

Gaumaz, L 1964. Het ambt bij Calvijn in een samevatting naar zijn commentaren op het Nieuwe Testament, $\mathrm{tr}$ by $\mathrm{K}$ Deddens. Faneker: T Wever.

Hendriksen, W 1972. New Testament Commentary Ephesians. London: Banner of Truth Trust.

Milner, B C (jr) 1970. Calvin's doctrine of the Church. Leiden: EJ Brill.

Parker, T H L 1975. John Calvin. London: Dent \& Sons.

Pont, A D 1979. Die amp in die kerk. Pretoria: HAUM.

Van't Spijker, W 1994. Bucer's influence on Calvin: Church and community, in Wright, D F (ed), Martin Bucer: Reforming Church and Community. Cambridge: Cambridge University Press. 